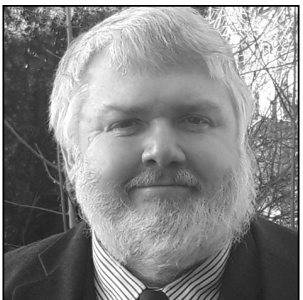

Patrick Praet

Attorney-at-Law, Ghent

\title{
Reflections on the COVID-19 Restrictions in Belgium and the Rule of Law
}

'Discipline to be effective must be optional.' - Lord Birrell of Blatherstone ${ }^{*_{2}}$

\section{Introduction}

\section{1.}

The start of the COVID-19 pandemic has elicited an astonishingly uniform response from states the world over. Their actions have ranged from recommending particular practices (e.g. social distancing), through mandating various precautions (e.g. masks and quarantine), to imposing full-blown restrictions on personal and economic liberty (travel bans, curfews, lockdowns, border closures, etc.).

Indeed, nearly all countries ${ }^{*} 3$ have resorted to seemingly identical measures of closure and control, although with intensities that have varied with time and place ${ }^{*}$. At the end of February $2021^{*}{ }^{5}$, no fewer than six EU member states still had a ban in force on non-essential travel to and from their territory, a practice that had already come under (albeit impotent) scrutiny from the European Commission. ${ }^{* 6}$

1 Although there is no determiner 'some' in the title, this article is not intended to provide the reader with an exhaustive account of the topic, which would be impossible for reason of space limitations in any case. Studying the Belgian example is justified by the country's representative approach to the pandemic and the legal complexity thereof.

2 The fictional British Minister of Justice created by Saki (HH Munro), 'The Easter Egg' in Collected Short Stories of Saki (Wordsworth Editions 1993) 138.

3 Actually, the only exceptions that spring to mind are Sweden and some states in the USA during the first wave of the pandemic.

4 We may note among the restrictions the banning of all non-essential movement (in Belgium), strict confinement to one's home (in France, Spain, and Italy), forbidding of mass gatherings and festivals (in all countries considered), and curfews (in France, Belgium, and the Netherlands). The Blavatnik School of Government at Oxford University has introduced a convenient tool that compares and quantifies the restrictions in 180 countries, available at <https://covidtracker.bsg.ox.ac.uk/ stringency-scatter>accessed 27 February 2021. At that time, Afghanistan ranked at the bottom of the strictness table, with a score of $12 \%$ whereas Estonia was rated $60 \%$ of the maximum.

5 This article was written in late February 2021 and updated in early August.

6 The member states concerned were Belgium, Sweden, Germany, Hungary, Finland, and Denmark. See <www.schengenvisainfo.com/news/eu-commission-urges-six-member-states-to-remove-some-of-their-covid-19-border-restrictions/> . 
Odd though it may seem, these unprecedented restrictions of traditional liberties in $2020^{*} 7$ have met both in Belgium and in the European Union with precious little criticism by the press, limited political opposition and only a handful of protest marches and riots ${ }^{*}$.

Likewise, judicial review of the restrictions has been rather limited. This too seems odd, given the sensitive debate about the role of the judiciary and their perceived juristocracy and judicial activism ${ }^{*}$.

Of course, there had been warnings of dire consequences, from various quarters, but none too much In Germany, former President of the German Federal Constitutional Court Hans-Jürgen Papier admonished in an interview ${ }^{* 10}$ : 'As a constitutional lawyer, I could never have imagined that such intense restrictions on freedom would be decided by the second power, the executive [...]. The people in this country are not subjects.'

In Italy, the Tribunale Ordinario di Roma ruled in December 2020 that several of the measures carried out were illegal, even within the context of the country's state of emergency: 'There is no constitutional or other legal basis that gives the Council of Ministers the power to declare a sanitary emergency [...]. It follows that all resulting administrative measures are unlawful. ${ }^{*{ }_{11}}$

In France, in turn, two hundred prominent lawyers published an open letter ${ }^{* 12}$ declaring the following: 'As lawyers, we also warn in particular about twisting the law. Any state of exception, even justified by an exceptional health situation, implies a risk of drift. Thus our law is now subject to the technical-scientific injunction of doctors and the Scientific Council, who impose their vision to the detriment of a more global political vision which must balance different interests.'

\section{2.}

In the present paper, we will try to make sense of this constellation of phenomena by addressing both the legality of the restrictions enacted in Belgium and their legitimacy, considered in a broader, philosophical context.

To this end, we begin with a general outline of the requirements of the rule of law in times of a pandemic, then scrutinise the restrictions implemented by the Belgian federal government.

Naturally, the proverbial elephant in the room here is the unprecedented predominance of the executive power, acting by its own device (or, rather, at the instigation of virologists ${ }^{{ }^{1} 13}$ ), for most measures have been implemented without large amounts of international co-operation, with precious few consultation of the legislative power, sometimes within conveyed emergency powers but always with far reaching consequences for the rights and liberties of the individual.

In the concluding part attention is paid to the possibly huge ramifications for some areas of wider debate in the philosophy of law and its classic topoi such as the boundaries between ethics and law, utilitarianism, trias politica, constitutionalism, sovereignty, and the rule of law. ${ }^{* 14}$

7 In particular, the following fundamental rights are at issue: freedom of religion and belief (art 9 ECHR and art 10 EU Charter); the right to private life, including family life and inviolability of the home (art 8 ECHR and art 7 EU Charter); freedom of assembly and demonstration (art 11 ECHR and art $12 \mathrm{EU}$ Charter with regard to assembly); freedom of education (art 2 ECHR and art 14 EU Charter); the right to property (art 1 of First Protocol (EP) ECHR and art 17 EU Charter); freedom to conduct business (art 16 EU Charter); and freedom of movement (art 2 of Protocol 4 ECHR and art 45 EU Charter).

8 Note the stark difference from the fury of the gilets jaunes in France and other political upheaval in recent years.

9 For a vigorous attack, see J Sumpton, 'Judicial and Political Decision-making: The Uncertain Boundary' (FA Mann Lecture) (2011) Judicial Review Vol. 16 (4). - DOI: https://doi.org/10.5235/108546811799320844. Contra: S Sedley, 'Judicial Politics' (2012) 34 London Review of Books 15 Judicial Review. - DOI: https://doi.org/10.5235/108546812801228103.

10 See <www.nzz.ch/international/hans-juergen-papier-warnt-vor-aushoehlung-der-grundrechte-ld.1582544?reduced=t rue> accessed 13 July 2021.

11 Tribunale Ordinario di Roma of 16 December 2020, 45986/2020, via <www.cassazione.net> accessed 13 July 2021.

12 See <www.spectator.co.uk/article/libert-an-open-letter-by-200-french-lawyers-protesting-against-lockdown> accessed 13 July 2021.

13 In Belgium, imminent changes in policy have routinely been announced initially on television, by the advising virologists, rather than through their publication in the state gazette.

14 One need not emphasise that clear delimitation of these topics is not always possible; for instance, while the panmedicalisation of society as criticised by André Comte-Sponville ( $<$ www.challenges.fr/economie/andre-comte-sponville-face-a-la-crise-du-coronavirus-gare-au-pan-medicalisme_704287> accessed 13 July 2021) is an ethics issue, the questions of mandatory vaccination and vaccine passports touch upon legal and economic issues as well. 
The final remark deals with the effect of the restrictions on the unspoken social contract between the people and the state. Until very recently, personal freedom, understood as the absence of coercion, was so central to the self-understanding of the proud Western citizen that absolutely nobody, with the exception of Peter Sloterdijk ${ }^{*}$, could have predicted the current state of affairs, which resembles fifty shades of lockdown.

The question remains open as to whether the repeated lockdowns of 2020 and 2021 will go down in history as a unique set of events never to be repeated again or as a watershed moment between a previously free society and a permanent state of crisis management that knows no politico-legal boundaries.

\section{The Rechtsstaat in times of emergency}

\section{1.}

In his Grundlinien der Philosophie des Rechts, G.W.F. Hegel sought to integrate subjective rights of the individual with the rational authority of the state. In doing so, he captured the core project of modern political thought, to 'combine the right of subjective liberty with the collective authority of society without subsuming either pole to the other" ${ }^{\text {* } 16}$.

The ensuing concept of the Rechtsstaat ${ }^{* 17}$, articulating state power and law as the fundamental principles of political philosophy, sits right at the heart of modern legal and political self-understanding, together with the notion of democracy.

In spite of the notion's centrality, there exists no authoritative definition of the concept Rechtsstaat and different approaches may be taken to the concepts of separation of powers and constitutional review amongst others ${ }^{*} 18$.

It is nonetheless possible to identify some core elements and consensus on a minimum set of criteria that any Rechtsstaat should meet. The foremost criterion is that a Rechtsstaat does not hold unchecked authority for it is subordinated by its own positive law. In other words, the principle of legality prevails.

The second requirement is the differentiation of government power into a legislature, an executive arm, and a judiciary. Thirdly, a legal remedy and recourse to an independent judiciary is required.

Usually, these three formal principles are supplemented by two substantive approaches: equality before the law and fundamental rights. This inclusion of substantive criteria of justice, even extra-legal values, has led to the concept of material Rechtsstaat.

The old discussions about formal legality and substantive legitimacy, about law versus justice, are no longer centred on natural law concepts but rather, they find their expression in the rights discourse, introducing a 'thick' type of (international) legitimacy based on fundamental rights.

The terms Rechtsstaat and 'rule of law' are not an identical match but are nonetheless frequently used as interchangeable concepts. For instance, EU publications do not problematise the term Rule of Law at all but simply use it as the mere translation of Rechtsstaat and its equivalents in other languages.

Neil McCormick has pointed out the (obvious) distinction that the Rechtsstaat presupposes the existence of a state, which is not necessarily a constitutive requirement for the Anglo-Saxon rule of law, in which the courts play a pivotal role ${ }^{* 19}$. Also, under the rule of law, the state is subordinated to a plurality of sources

15 Quite early on in the pandemic, on 18 March 2020, the German philosopher predicted that the Western system would become as authoritarian as the Chinese response, per <https://lepoint.fr/politique/sloterdijk-le-susteme-occidentalva-se-relever-aussi-autoritaire-que-celui-de-la-chine-18-03-2020-2367624_20.php> accessed 13 July 2021.

16 R Fine: 'Hegel's Critique of Law: A Re-appraisal' in R De Lange and K Raes (eds), Plural Legalities: Critical Legal Studies in Europe (Recht en Kritiek, 1991) 239.

17 In his book Die Polizei-Wissenschaft nach den Grundsätzen des Rechtsstaates, from 1832, Robert von Mohl (1799-1875) expressed the notion of opposition between the gesetzmässige Verwaltung of the law-abiding administration in a Rechtsstaat and the arbitrariness of government in the Obrigkeitsstaat, or authoritarian state.

18 E-W Böckenförde, 'The Origin and Development of the Concept of the Rechtsstaat' in E-W Böckenförde, State, Society and Liberty (1991); R Grote, 'Rule of Law, Rechtsstaat and État de droit' in C Starck (ed), Constitutionalism, Universalism and Democracy - a Comparative Analysis (1999); K Tuori, 'Four Models of the Rechtsstaat' in W Krawietz and W von Wright (eds), Oeffentliche oder private Moral. Festschrift für Garzon Valdes (1992).

19 N McCormick, 'Der Rechtsstaat und die Rule of Law' [1984] Juristen-Zeitung 65; M Bennett, 'The 'Rule of Law' Means Literally What It Says: The Rule of the Law: Fuller and Raz on Formal Legality and the Concept of Law' (2007) 32 Australian Journal of Legal Philosophy 90. 
and principles, some of which might even be external or pre-political even to the point of being assimilated to moral principles.

These differences notwithstanding, the Rechtsstaat-concept is compatible with the generally accepted irreducible minimum content of the rule of law as famously formulated in Joseph Raz's famous principles for the rule of law $^{*}{ }^{20}$.

\section{2.}

The primary feature of any law-based state is the subjugation of government to standards of substantive and procedural legality, even during a pandemic. This continuing normativity has been clearly spelt out by numerous international institutions.

As early as April 7, 2020, barely a month after the general outbreak of the pandemic, the Council of Europe issued a document titled 'Respecting Democracy, Rule of Law and Human Rights in the Framework of the COVID-19 Sanitary Crisis: A Toolkit for Member States Available in Different Languages', which highlights the obligations of the contracting states ${ }^{* 21}$. In this document, the council gives a brief but comprehensive overview of the permissible derogations from the states' obligations in times of emergency and repeats that it is for each state to assess what measures are necessary and to judge whether the intended measures warrant a derogation, in which case a notification has to be submitted to the Secretary General of the Council of Europe. The measures may of course come under assessment by the European Court of Human Rights (ECtHR) ${ }^{*} 22$.

It is reiterated that a derogation under Article 15 is not contingent on formal declaration of a state of emergency; rather, any derogation must have a clear basis in domestic law (the principle of legality) in order to protect against arbitrariness and must be strictly necessary for fighting the public emergency (proportionality-principle).

The rule of law has to be respected and the emergency measures and general powers to issue decrees both need to be limited in time. Restrictions on freedoms guaranteed by articles $8,9,10$, and 11 are permissible only if they are established by law and proportionate to the protection of health. In contrast, indefinite perpetuation of the exceptional powers of the executive is impermissible.

A further principle specified in this connection is that the emergency measures must achieve their purpose with minimal intervention in the normal rules of decision-making: parliaments must retain the power to verify whether the emergency powers of the executive are still justified, and, likewise, the core function of the judiciary - in particular, that of the constitutional courts - should be maintained.

The last but by no means least principle articulated in the document is that certain articles such as those on the right to life (Article 2) and the prohibition of torture and inhuman or degrading treatment/punishment (Article 3) must never be subject to any derogation.

Finally, the toolkit rounds out the discussion by issuing a reminder of the positive obligation of the signatory states to cope with infectious diseases by taking all necessary emergency measures in cases of epidemics (in line with Article 11 of the European Social Charter).

Warnings have been issued also with regard to derogations from the International Covenant on Civil and Political Rights (ICCPR), adopted by United Nations General Assembly Resolution 2200A (XXI) on 16 December 1966. In May 2020, the Human Rights Treaties Branch of the UN released a toolkit addressing treaty-law perspectives and jurisprudence in the context of COVID-19. Its opening paragraphs remind the user in no uncertain terms of the principles set forth in the ICCPR and nine other UN treaties and covenants shielding rights of particular groups in society:

20 J Raz, 'The Rule of Law and Its Virtue' in The Authority of Law: Essays on Law and Morality, Oxford, 1979). - DOI: https:// doi.org/10.1093/acprof:oso/9780198253457.003.0011.

21 Council of Europe, 'Respecting Democracy, Rule of Law and Human Rights in the Framework of the COVID-19 Sanitary Crisis: A Toolkit for Member States Available in Different Languages'; see <www.coe.int/en/web/echr-toolkit> accessed 13 July 2021.

22 In the jurisprudence of the European Court of Human Rights, matters of health-care policy, 'in particular as regards general preventive measures, are in principle within the margin of appreciation of domestic authorities who are best placed to assess priorities, use of resources and social needs' and 'it is not excluded that a positive obligation might arise to eradicate or prevent the spread of a particular disease or infection' (Shelley $v$ UK 23800/06 (ECtHR, 4 January 2008). See also Öneryildiz $v$ Turkey 48939/99 (ECtHR, 30 November 2004); Kolyadenko e.a. $v$ Russia 17423/05, 20534/05, 20678/05, 23263/05, 24283/05 (ECtHR, 28 February 2012). 
The challenges unfolding with the COVID-19 pandemic impact the whole spectrum of human rights. This includes abuse of derogations, protection of vulnerable groups and people deprived of their liberty, women's rights, minorities as well as economic, social and cultural rights. In the midst of a sanitary crisis, as the one generated by the spread of COVID-19, it is essential to ensure the enjoyment of all human rights, without discrimination.

As the High Commissioner has stated, 'an emergency situation is not a blank check to disregard human rights obligations'. More than ever, States must uphold the obligations that they are legally bound to meet under the treaties they have ratified.

The ICCPR allows for limited derogation in cases of health emergencies, in keeping with the Siracusa Principles on the Limitation and Derogation Provisions in the International Covenant on Civil and Political Rights, set forth by the International Commission of Jurists (ICJ) ${ }^{{ }^{2} 3}$.

Last but not least, the European Commission's 2020 Report document on the rule-of-law situation in the European Union ${ }^{* 24}$, released on 30 September 2020, reminds the member states, on page 2:

The rule of law is enshrined in Article 2 of the Treaty on European Union as one of the common values for all Member States. Under the rule of law, all public powers always act within the constraints set out by law, in accordance with the values of democracy and fundamental rights, and under the control of independent and impartial courts. The rule of law includes principles such as legality, implying a transparent, accountable, democratic and pluralistic process for enacting laws; legal certainty; prohibiting the arbitrary exercise of executive power; effective judicial protection by independent and impartial courts, effective judicial review including respect for fundamental rights; separation of powers; and equality before the law.

It continues with a statement that the

particular circumstances of 2020 have brought additional challenges to citizens' rights, and [that] some restrictions on our freedoms, such as freedom of movement, freedom of assembly or freedom to conduct a business, had to be applied to address the COVID-19 pandemic. Effective national checks and balances upholding respect for the rule of law are key to ensuring that any such restrictions on our rights are limited to what is necessary and proportionate, limited in time and subject to oversight by national parliaments and courts.

\section{3.}

The clear warnings to the signatory states of these international treaties have been duly matched by equally clear and eloquent opinions from national administrative courts, amongst others the Dutch and Belgian highest administrative courts.

At the request of the Dutch Parliament, the Dutch Council of State, or Raad van State, issued a concise yet clear 'Advice on the constitutional aspects of the intended crisis measures" ${ }^{\text {"* }}$.

In the advice, the Council of State admonished that in order to be allowed to restrict fundamental rights, the requirements set by the Constitution and treaties must be met. An important requirement in treaties is that restrictions be sufficiently clear and necessary for the purpose they serve. The Constitution requires that restrictions always be traceable to a specific law in a formal sense. These requirements are cumulative. It is also important that the corona measures also guarantee fundamental rights. For example, it follows from the Constitution and treaties that the government must actively promote and protect the right to health and the right to life.

The Council of state's Advisory Division has established, further, that 'the power to radically restrict fundamental rights in a (model) regulation does not, strictly speaking, correspond to the specific legal basis

23 N Sun, 'Applying Siracusa: A Call for a General Comment on Public Health Emergencies' (Viewpoint) [2020] (23 April) https://www.hhrjournal.org/2020/04/applying-siracusa-a-call-for-a-general-comment-on-public-health-emergencies/> accessed 13 July 2021.

24 Commission, 'Rule of Law Report - the Rule of Law Situation in the European Union' COM (2020) 580 final; see <https:// eur-lex.europa.eu/legal-content/EN/TXT/PDF/?uri=CELEX:52020DC0580\&from=EN> accessed 13 July 2021.

25 Advice of 7 May 2020, available in Dutch at <www.raadvanstate.nl/?ActLbl=w04-20-0139-vo\&ActItmIdt=121106 > accessed 13 July 2021. 
required by the Constitution for the restriction of fundamental rights'. It was stated that a case could be made, 'however, that in the acute, concrete and life-threatening initial phase of the pandemic, the government has sufficed with a more general legal basis'; that said, 'the emergency ordinances cannot provide a basis for a ban on meetings in the strict private sphere'.

The advice pointed out also that ' $[t]$ he longer this situation lasts, the longer the legal sustainability of the emergency ordinances. That is why the government has rightly decided to make a temporary law that will replace the emergency ordinances in the short term'.

When, likewise, the Belgian government applied for special powers, that country's Council of State (Raad van State or Conseil d' Etat) had to express its opinion on the legality of the proposal for a law, which it produced in plenary session ${ }^{* 26}$.

Although its Opinion of 25 March 2020 fielded several technical and logical objections and clarifications, the main point of focus was the council's insistence that the executive entity must always check whether the decision is in accordance with the higher standards of the law: the Constitution and the international treaties. The latter were deemed particularly relevant with regard to isolation measures, restrictions on freedom of movement, measures limiting contacts between members of the same family, the closure of schools and universities, etc.

The council's advice features the specific conclusion that the respect shown for private and family life; freedom of thought, conscience, and religion; freedom of expression and assembly and of association; and the right to education must be in accordance with the fundamental rights as protected by the European Convention on Human Rights (ECHR).

Also, the measures must be necessary (though not absolutely necessary) in the interests of the country's security, public security, the economic well-being of the country, the protection of public order and prevention of criminal offences, the protection of health, or the protection of the rights and freedoms of others.

Moreover, the regulatory instruments envisioning interference with these rights must always be clear, foreseeable in their effect, and proportionate to the objectives pursued.

Hence, one can conclude that neither the Dutch nor the Belgian Council of State's advice differs from what is articulated in the above-mentioned toolkits, advices and opinions issued by the international institutions.

All the various opinions presented, both international and national, above render it crystal clear that an executive power does not operate in a legal vacuum and does not enjoy free rein to combat a pandemic by whatever means.

On the contrary, it appears that the executive power's actions have to meet the cumulative criteria set forth by the relevant bodies, which can summed up as:

(a) to act within the constraints set out by the law;

(b) to act in accordance with the values of democracy and fundamental rights;

(c) to operate under the control of independent and impartial courts;

(d) to ensure that the restrictions on the rights are limited to what is necessary and proportionate.

\section{Assessment of Belgium's COVID-19-based restrictions}

\section{1.}

At the advent of the crisis, Belgium was ruled by a caretaker minority government that did not command a majority in Parliament. Political convention is for such a government to refrain from introducing new or far-reaching policies. Nonetheless, this government reacted to the crisis in largely the same hyper-dynamic vein as the neighbouring countries - i.e., by closing the nation's borders and schools and by shutting down its hospitality and culture industries, alongside all shops deemed non-essential. Moreover, all non-essential movement outside the home was forbidden from 18 March 2020 onward. Thus, the so-called first lockdown began.

26 Belgian Council of State, Opinion 67.142/AV, of 25 March 2020. 
Only post factum did the government ask Parliament for special powers to legitimise these actions. Parliament duly obliged and retroactively conferred special powers on $i^{{ }^{*}}{ }^{27}$ for a span of three months, from 28 March, thereby granting more power to a minority caretaker government than a regular majority government normally would have possessed in normal times

The summer of 2020 ushered in some relaxation to the restrictions, but 18 October 2020 brought the reintroduction of a great number of restrictions, accompanied by a new measure not seen since the German occupation: a general curfew in force between midnight and five o'clock in the morning. ${ }^{*} 8$ In other new rules, the number of personal contacts allowed was reduced to just one person per occasion indoors and four people outdoors ${ }^{* 29}$. From 18 February 2021, non-essential travel to and from Belgium was forbidden once more, under a ban that lasted until 19 April 2021.

In the meantime, the special powers had expired and a new government (commanding a regular majority in Parliament) had come into office (doing so on 1 October 2020). Therefore, the restrictions imposed in autumn 2020 will have to be judged within the framework of the regular legislative process.

\section{2.}

According to the formulation of the four criteria we have distilled from the international advice and toolkits on the rule of law during a pandemic, the foremost criterion for the government is to always act within the constraints set out by the law.

It has to be noted that the Belgian Constitution does not allow its suspension, not even partially (per Article 187 of the co-ordinated version of 17 February 1994). Therefore, a state of emergency shall not be proclaimed. Moreover, at the outbreak of the pandemic, Belgium did not have a special law dealing with health emergencies. Parliament handed special powers to the government for the initial three months in 2020, but no material constraints were set forth. No special powers were requested or given in autumn 2020. In addition, a pandemic-related bill was not proposed by the government until 3 March 2021 and was finally enacted on 15 July 2021.

Therefore, in autumn 2020 it was up to the government to react to the pandemic by exercising its ordinary regulatory powers under Article 108 of the Constitution: the King (i.e. the Government) 'makes the decrees and takes the decisions necessary for the implementation of the laws, without ever being allowed to suspend the laws themselves or grant exemption from their implementation'.

The Constitution does not, however, provide that a single minister could be granted the power to act in a regulatory capacity, let alone restrict fundamental rights. In practice, ministerial decrees are typically used to set out technical details, not to regulate ${ }^{*} 30$.

In contrast, though, virtually all COVID-19-related restrictions were introduced via several ministerial decrees (usually issued by the Minister of the Interior) rather than by royal decree (decided upon by the entire government) or a law proper (enacted by Parliament) ${ }^{*} 31$.

27 The law of 27 March 2020 empowering the King to take measures to combat the spread of the COVID-19 virus, published in the Moniteur Belge/Staatsblad (the official gazette) on 30 March 2020. According to Belgian constitutional practice, a special-powers act is characterised by the granting of a power of regulation to the executive (dubbed 'the King'), who, in the exercise of that power, may supplement and amend laws via application of wide discretionary power. The legal basis for this is art 105 of the Constitution, which states that the King has no power other than the power expressly granted to him by the Constitution and by the special laws enacted under the Constitution itself. Any special-powers law must meet the following conditions: there must be exceptional factual circumstances that determine the limits of the period during which special powers may be granted; secondly, the special powers are to be assigned for a limited term only; the powers conferred on the King must be precisely defined with respect to purposes and objectives, as well as with regard to the matters with regard to which measures may be taken and their scope; the legislator must respect supranational norms, international norms, and constitutional rules of jurisdiction when granting special powers; and the law may not prejudice the division of powers among the (federal) state, the communities, and the regions.

28 This is the curfew imposed nationwide by the federal Minister of the Interior. Said ban was extended to 10pm by regional governments in the Brussels capital area and the Walloon region (the French-speaking part of the country). The federal and regional curfews stayed in place until 8 May 2021.

29 The new Minister of the Interior's micro-management even made it to the Washington Post: 'Belgians can invite guests for Christmas dinner, but only one can use the bathroom' https://www.washingtonpost.com/world/2020/12/02/belgiumcoronavirus-christmas-bathroom/.

30 P Goffaux, Dictionnaire de droit administratif, Brussels, 2016, 355; VC Behrendt, M Vrancken, Principes de droit constitutionnel belge, Bruges, 2019, 340.

31 In French Arrêté ministeriel, Arrêté royal and Loi, respectively. In Dutch Ministerieel Besluit, Koninklijk Besluit, and Wet. 
The first problem of legality, therefore, is the wrong type of instrument used to bring in the restrictions, notably a decree by a single minister rather than a decree by the assembled government.

The second problem involves the legal basis for these ministerial decrees. Invoked as their basis was the Civil Security Law of 15th May 2007, which allows the Minister of the Interior, when there is a threat of calamitous events, catastrophe, or disaster, to prohibit any displacement or movement of the population where said prohibition is aimed at ensuring the protection of the population. Reference was made also to the Civil Protection Law of 31 December 1963 and the Police Function Law of 5 August 1992.

The problem with these law is that they were unequivocally intended for acute, local emergencies (e.g. floods, gas leaks) as opposed to deep and protracted interference with an entire population. Competence established on this basis was therefore stretched beyond limits. Indeed, plenty of constitutional lawyers, as well as every bar association in the country, have questioned the legal foundations of the government measures based on ministerial decrees ${ }^{*}{ }^{32}$.

The government too clearly recognises this issue, as evidenced by it finally having submitted a Pandemic Law proposal to Parliament (on 3 March of this year) ${ }^{*} 33$.

\section{3.}

The second element, respect for the values of democracy and fundamental rights, cannot be disconnected from the fourth, limitation of the restrictions on rights to only what is necessary and proportionate.

The curtailing of the fundamental rights by the restrictions is obvious, but the legality thereof depends entirely on whether the restrictions in question are correctly established by law and strictly proportionate to the protection of health.

As was pointed out in the above-mentioned opinions from the Council of Europe, the European Commission, and the Human Rights Treaties Branch of the UN, restrictions on fundamental rights are admissible only if they are imposed in pursuit of a legitimate aim necessary in a democratic society and if the grounds for the restriction are relevant with regard to the objective pursued.

One can easily imagine that protecting the right to health of the citizens is a relevant objective, if not a duty, of the government. However, if the restrictions are to be legal, they must also be proportional to the aim pursued, and if there are other ways of achieving this that are less restrictive to our rights and freedoms, the latter measures must be adopted.

Confining all members of the population to their domicile at night would appear out of proportion to the stated goal because, for the aim of reducing the number of house parties and drunken gatherings (the goal that the preamble of the corresponding ministerial decree explicitly states for the measure), a less intrusive ban on groups gatherings would have sufficed.

The same is true for the blanket ban on foreign travel. This, in turn, seems disproportional since a quarantine and testing system (already in place) should have been sufficient to stop the import of viruses of foreign origin. Both the curfew and the travel ban were introduced to facilitate control and policing, and they added few other benefits ${ }^{*} 34$.

In assessing the proportionality of the restrictions, it is also important to bear the time factor and the material circumstances in mind. With the first lockdown, the aim was to reduce the burden on the hospitals and the health sector in general. Here, the precautionary principle may have been rightly cited as the rationale for lockdown measures: as there were indeed insufficient face masks and other personal protective

32 Available at <https://plus.lesoir.be/354163/article/2021-02-10/20000-avocats-rappellent-le-gouvernement-ses-devoirsdemocratiques> accessed 13 July 2021. This open letter was particularly candid and harsh by Belgian genteel political standards, viz 'Some seem to believe that a social order can be adapted based on what scientists or policy-makers believe is necessary, desirable, or reasonable. They are wrong. In a democracy, the social order is based on rules and procedures defined in particular by the Constitution and European or international treaties. This order can be adjusted, but only according to the rules provided. Otherwise, the door is open to arbitrariness, abuse of power and ultimately tyranny.'

33 At the of editing, the Spanish Constitutional Court declared the first lockdown unconstitutional because in Spain too, the wrong legal mechanism was used (a mere state of 'health alarm' instead of the required 'state of emergency' imposed by the constitution) <www.reuters.com/world/europe/spanish-court-says-covid-19-state-emergency-was-unconstitutional2021-07-14>accessed 8 August 2021.

34 A cynic might assert that the government singled out these two measures because of their marginal effect on most people's lives thereby allowing the government to appear to act strongly without actually hurting many of its voters. 
equipment available, strong measures such as total lockdown ${ }^{*} 35$ seemed warranted to impede the spreading of the new, unknown virus.

Indeed, the pandemic was new at that time, and little was known about the virus's virulence. Herein lies a strong argument in favour of proportionality during the first wave of the pandemic, in the spring of 2020.

In the meantime, however, many of the medical parameters have changed for the better: the availability of protective equipment; vaccination of the clinically vulnerable, now well underway in all EU member states; and, last but not least, hospital treatment, improvements to which have further reduced the mortality rate, which was already low in the general population anyway ${ }^{*}{ }^{6}$.

In a wider context, the financial burden on the treasury, the crippling of the economy, and the psychological damage to the population should have been taken into consideration too, since the cost of these factors has risen dramatically over time.

In other words, the parameters of the pandemic have changed to such an extent that any blanket lockdown has by now, in the current wave of the epidemic, lost most of its initial rationale, such that the prolonged suspension of civil liberties appears to be disproportionate to the actual health threat for the general population.

This is clearly not the view shared by many governments, though, including Belgium's. Rather, it seems to have become the aim of the government and its advisory bodies to maintain the measures stubbornly or reintroduce them in aims of achieving a society with zero SARS-CoV-2 infections.

It bears repeating here that the treaties allow a large margin of appreciation ${ }^{*} 37$ with regard to the escape clauses for 'public health' and 'public order'. As there are arguments pro and contra, it will be interesting to see how the European Court of Human Rights and other jurisdictions will rule on related matters when and if they have their final say in this respect.

\section{4.}

The third criterion, acting under the control of independent and impartial courts, has posed no problem, since courts have been open for operation throughout the pandemic and remained accessible under normal rules, distancing requirements and delays notwithstanding.

It should be noted that Belgium's administrative supreme court, the Council of State, has not stricken down provisions of the ministerial decrees, with the sole exception of the blanket ban on church gatherings ${ }^{*}{ }^{3}$.

On 21 March 2021, the Court of first Instance in Brussels declared all the COVID-19 restrictions void and illegal in summary proceedings and gave the government 30 days to develop appropriate modifications (in case 2021/14/C). This decision was revisited by the Brussels Court of Appeal (in case 2021/KR/17) on 7 June 2021 because the first judge had overstepped the bounds of authority by making general rules and by exceeding the limits of the framework for summary proceedings.

However, the Court of Appeal ruled also that, although the ministerial decrees in question do have a prima facie legal basis, this legal basis might be flawed if interpreted in light of the ECHR. According to the Court, there is a problem with the constitutionality of the measures too, because the power to restrict the fundamental rights rests in the hands of a single minister. Furthermore, the imposition of criminal

35 Apart from infringing fundamental rights, some restrictions were downright inimical to human nature itself. Being barred from visiting elderly family in retirement communities, assisting parents in their final hours, attending funerals of loved ones, etc. seem particularly cruel and inadmissible.

36 In Belgium, the numbers on 10 July 2021 stood at 1,093,700 infections and 25,198 fatalities. See <https://covid-19.sciensano.be/sites/default/files/Covid19/Meest\%20recente\%20update.pdf> accessed 13 July 2021.

37 A Legg, 'The Margin of Appreciation in International Human Rights Law: Deference and Proportionality', Oxford, 2012, DOI: https://doi.org/10.1093/acprof:oso/9780199650453.001.0001, as reviewed by A Von Staden (2013) 13 (4) Human Rights Law Review 795.

38 The Belgian Council of State has turned down all but one summary appeal against the lockdown decrees: case numbers 249.315, of 22 December 2020; 217.674, of 28 May 2020; 248.131, of 8 August 2020; 248.162, of 8 August 2020; and 248.819, of 10 October 2020. Not only did the council state that there were no prima facie illegalities in the decrees (without discussing the margin of appreciation), but it even suggested proprio motu that art $23,3,2^{\circ}$ of the Belgian Constitution puts the state under the obligation to protect public health. The only exception here was case 249.177 , of 12 December 2020 , in which the ban on all religious services apart from burials and marriages (with maximum attendance of 15 people) was deemed unreasonable. In this instance, the council ordered the government 'not to limit the collective expression of religion in an unreasonable manner'. 
sanctions on the sole basis of ministerial decrees has been deemed unconstitutional. Still, the Court decided not to rule on these matters but leave them to the Constitutional Court of Belgium, before which are pending several cases.

Other cases in this domain are still awaiting trial, though some rulings have already been issued by lower courts. Courtrai and Charleroi (dealing with refusal to pay the fines specified for breach of the restrictions) have declared the ministerial decrees invalid ${ }^{*} 39$.

\section{The 'new normal' and the ramifications for the philosophy of law}

What will this bold reaffirmation of the political over the law and the concomitant disregard for the rule of law hold for future dealings between the government and the citizenry once the pandemic is overcome? Will the unspoken social contract based on the liberal Rechtsstaat survive, or will a 'new normal' emerge? In other words, what will the new equilibrium look like once the phases of acute crisis management and stabilisation have run their course?

According to Niels Bohr's classic tongue-in-cheek analysis, 'predictions are very difficult, especially if they are about the future'. With the crisis far from over, it is too early to assess the changes in the superstructure of intellectual reception. That said, several prophecies and observations about likely topics and controversies in academia and general society alike seem permitted.

The first topic one might identify for academia is a reawakening of the national state as the prime field of reference. Hitherto problematising the transformative decline of the sovereign state and the emergence of the European Union as a 'polycentric, pluri-systemic, multi-state legal order, ${ }^{*} 40$ the literature may have to prepare for a U-turn. During the pandemic, governments and populations alike considered not the European Union (let alone the world community) but the national state to be their sole frame of reference for protection and isolation ${ }^{*}$. Borders were abruptly closed without prior consultation, and at some point medical equipment for intra-community export was confiscated for national use. The EU institutions stood idly by and were unable to resuscitate European solidarity. Add to this the chilling debacle of the joint procurement of vaccines early 2021, and it is clear that the waning of the national state and the emergence of a European demos seems further away than ever.

A second perspective that will have to be adjusted is the spectre of a juristocracy ${ }^{*} 42$ through rampaging judicial review. The academic fear of judges determining the scope and boundaries of policy has evaporated before our eyes. With few exceptions, the courts have shown great understanding for government COVID-19 policies and have emphasised that the executive power possesses a wide margin of appreciation with regard to the proportionality of its actions.

The third shock one can point to is that the discourse of fundamental rights, hitherto seemingly written in stone, did not stand up to the commandment of the hour, instead the doctrine of 'Salus patriae suprema Lex (est)' made a come-back ${ }^{*} 43$. Moreover, the majority of the population seemed and seems to be quite prepared to make a trade-off between freedom and security ${ }^{*} 44$.

39 Tribunal de Police du Hainaut, Charleroi division, 20CI12105, 21 September 2021; Rechtbank van Eerste Aanleg WestVlaanderen, Courtrai,divsion, 21K000402, 21 May 2021.

40 N McCormick, Questioning Sovereignty, Oxford, 1999, 105. - DOI: https://doi.org/10.1093/acprof:oso/97801 98268765.001.0001.

41 On 9 July 2021, Malta announced, in clear defiance of the EU Vaccination Passport scheme, that it would be closing its borders to anybody who has not been vaccinated twice.

42 C Gearty, Can Human Rights Survive?, Cambridge, 2002. - DOI: https://doi.org/10.1017/cbo9781139167369.007; R Hirschl, Towards Juristocracy: The Origins and Consequences of the New Constitutionalism(2006) International Journal of Constitutional Law, 4(3), 581-586. - DOI: https://doi.org/10.1093/icon/mol020. P Neil, 'The European Court of Justice: A Case Study in Judicial Activism', 1995, London, European Policy Review: P Praet, 'Politisierung des Rechts oder Verrechtlichung der Politik - Diskurs der Grundrechte' (2007) 38 Rechtstheorie (Heft 2/3) 367.

43 Translated as 'the welfare of the fatherland is the supreme law'.

44 D De Coninck, L d'Haenens Leen, and K Matthijs, 'Perceptions and Opinions on the COVID-19 Pandemic in Flanders, Belgium: Data from a Three-Wave Longitudinal Study' (2020), 32, Elsevier Data in Brief, October 2020, 106060. - DOI: https://doi.org/10.1016/j.dib.2020.106060. Even after the pandemic, a sizeable chunk of the population would choose to 
These are phenomena that will no doubt be studied for a long time to come. All it has taken is one pandemic (not even of the worst possible kind), and entire libraries about the inviolability of human rights and the decline of the national state can be relegated to Makulatur, waste paper.

Another observation is that virtue ethics ${ }^{*} 45$ have made a sudden return to public discourse. In the modern worldview, law became increasingly disconnected from substantial ethics, to the extent that everything not prohibited was ipso facto permitted. Hereby, ethics became consigned to private realms - reduced to a matter of opinion, so to speak ${ }^{*} 46$. The state was supposed to be neutral and not favour any life choice over another. This attitude has changed amid the continuous appeal to the solidarity of the population and with vociferous disapproval of anti-social, egoistic behaviour ${ }^{*} 4$. Holiday travellers are pilloried by public opinion, and leading Belgian virologist Erica Vlieghe has exhorted complainers to 'stop whining"* 48 .

In another observation, one can detect a rise of medical collectivisation and the technocracy of virologists $^{*} 49$. This new type of collectivisation has already manifested itself in three ways: 1) people are prohibited from engaging in risky behaviour, because of the burden on hospitals and the risk of virus transmission, 2) individuals are not permitted to procure their own vaccines on the private market, with inoculation being managed by government agencies instead, and 3) the entire population is urged to get vaccinated for the sake of society. The introduction of an overriding precautionary principle and of the mantra follow the science' among politicians has led to rule by virologists, epidemiologists, and other such experts, whose recommendations get rubber-stamped by politicians. This situation gives rise to the same sort of accountability problems witnessed with the EU comitology system: who appoints these experts, and to whom are they accountable?

A phenomenon related to this is another step toward technological surveillance. Society has once more moved further toward a panopticum of all citizens and their digitalised data (from track-and-trace systems, passenger-locator forms, quarantine paperwork, vaccination passports, etc.). Simultaneously, the introduction of vaccination requirements ${ }^{*}{ }^{0}$ creates tension with the non-discrimination principle enshrined in all constitutions in the world and the supranational treaties on human rights. Refusal to be vaccinated or demonstration of medical contraindications to vaccination among a significant portion of the population ${ }^{*}{ }^{2}$ is leading to division of the population into two categories: those who have the right to unencumbered travel and those who do not. As more and more countries introduce domestic vaccination requirements for museum and restaurant visits, this will tendency will only grow stronger.

At the level of underlying philosophy, one can also identify issues pertaining to the use of utilitarianism as the guiding principle for government policy. From the very beginning of the crisis, states have taken up arms against the virus, mobilising all assets at their disposal and stating that the aim is a society free from the SARS-CoV-2 virus. The imposition of restrictions was justified under the utilitarian credo 'the greatest security for the greatest number'.

However, a wide calculus of the overall benefits and costs of this policy was never presented ${ }^{*} 52$. From a utilitarian position, policies should always consider both the overall benefit (the number of human lives saved or, more accurately, the number of additional years of life saved) and the overall cost (including

keep the restrictions in place, per <www.ipsos.com/ipsos-mori/en-uk/majority-britons-support-extending-certain-covid19-restrictions-not-forever $>$ accessed 13 July 2021.

45 A MacIntyre, After Virtue (1985), Notre Dame; M Sandel, Liberalism and the Limits of Justice (1982) Cambridge.

46 JW Harris, Legal Philosophies (1997), London; B Oppetit, Droit et modernité (1998), Paris. - DOI: https://doi.org/10.3917/ puf.oppet.1998.02.

47 F Bellazzi and K von Boyneburgk, 'COVID-19 Calls for Virtue Ethics' (2020) 7 (1) Journal of Law and the Biosciences , Isaa056. - DOI: https://doi.org/10.1093/jlb/lsaa056.

48 https://www.vrt.be/vrtnws/nl/2021/02/28/erika-vlieghe-oproep> accessed 13 July 2021.

49 F Horton, 'Offline: The Coming Technocracy' (2020) 396 The Lancet 1869. - DOI: https://doi.org/10.1016/s01406736(20)32668-4.

50 At the time of writing, in February 2021, it had already become reality in Israel and was part and parcel of the British government's so-called roadmap to freedom. At the European summit of 25 February 2021, the EU leaders made advances toward an EU-wide vaccination passport, which became reality on 1 July 2021 (under the EU Digital COVID-19 Certificate Regulation).

51 This is all the more explosive because the anti-vaccination movement in Western Europe appears to be particularly strong among ethnic minorities. In the particularly multi-ethnic city of Brussels, nursing staff in large numbers (put at up to 40\%) continue to refuse vaccination, a much higher percentage than in the rest of the country.

52 B Peterson, 'How We Reason about COVID Tradeoffs' [2020] (62) The New Atlantis 69. 
future loss of life that arises from delays to medical care, along with the economic damage and psychological harm caused). In the case of COVID-19, gigantic cost items were disregarded. This is very odd, because the same calculus routinely takes place when rules are being introduced in such domains as road safety, health and safety at construction sites, and allocation of scarce medical resources. Apparently, there now exists some sort of inverted 'quantum utilitarianism' whereby the sheer gravity of the problem distorts all other parameters.

In an eighth remark, we can point to the looming state of permanent emergency alluded to above. According to Carl Schmitt ${ }^{*}$ 33, sovereignty lies in the power to proclaim an exception to the existing order. This is exactly what has happened with the lockdown and assorted policies: the executive arm has asserted its power and been rewarded for so doing via the public approval of the scared masses. That is, a powerful incentive is evident at the first signs of a future epidemic, or even a sneeze, to disregard the old-fashionedseeming criticisms connected with the rule of law and temporarily lock society down once more, thereby relegating freedom to the realm of nostalgia and oblivion.

The ninth lesson in our catalogue is that of the danger of state interventionism. In view of the past two decades' experiences with the creeping constriction of privacy in life in the name of multiple noble causes (anti-terrorism, anti-discrimination, anti-fraud, etc.), there exists a danger that, in a decade or so, the dramatic pandemic responses of 2020-2021 will prove to have been merely the dress rehearsal for much greater intervention in our sphere of day-to-day living - e.g. related to restrictions in the name of ecological targets for combating carbon emissions and climate change ${ }^{*} 54$.

Some authors have already grasped the new possibilities and have instrumentalized for their own goals. Among them is eco-philosopher Bruno Latour ${ }^{*} 55$, who stated:

The first lesson the coronavirus has taught us is also the most astounding: we have actually proven that it is possible, in a few weeks, to put an economic system on hold everywhere in the world and at the same time, a system that we were told it was impossible to slow down or redirect. [...]

What we need is not only to modify the system of production but to get out of it altogether. We should remember that this idea of framing everything in terms of the economy is a new thing in human history. The pandemic has shown us the economy is a very narrow and limited way of organising life and deciding who is important and who is not important. If I could change one thing, it would be to get out of the system of production and instead build a political ecology.

Likewise, anti-globalist and nationalist movements have sought to capitalise on the current crisis. They would like to see the global, open architecture of society reversed.

The tenth lesson from the pandemic is the extra-ordinary pace of ever-changing public policies whereby measures that seemed unimaginable one week become public policy the next.

Two evolutions spring to mind here. First, there is the recent introduction for domestic vaccine passports in crowded places such as bars, theatres and trains. At the time of writing this paper half a year ago, this seemed anathema to citizens and politicians alike but now, at the time of revision, the movement is picking up speed. Countries such as Danmark, France, Italy, Israel already bulldozered over liberal principles and subject their people to legal documentation in order to live a normal life ${ }^{*} 56$.

Secondlt, there is the urge for mandatory vaccination. At present, overall mandatory vaccination is not on the table in any European country yet but it has already been introduced in Greece and France for healthcare-workers ${ }^{*}{ }^{57}$. Likewise, in the US, several big corporations have made it a prerequisite for returning to

53 Carl Schmitt, Political Theology: Four Chapters on the Concept of Sovereignty (translation from the German original from 1922, 1985). Another insight from this book might be its articulation of the ascension of public health, an apotheosis that has seen it rise to become the overriding 'theological' first principle or dogma and the equating of vaccination scepticism with heresy.

54 Drieu Godefridi has warned against ecologism, or the totalitarian branch of the ecology movement. See The Green Reich: Global Warming to the Green Tyranny (Louvain-la-Neuve 2019).

55 Article originally published in French in the AOC online culture newspaper on 29 March 2020. English translation available at <www.theguardian.com/world/2020/jun/06/bruno-latour-coronavirus-gaia-hypothesis-climate-crisis > accessed 13 July 2021.

56 <https://www.liberation.fr/international/pass-sanitaire-face-au-covid-19-que-fait-le-reste-du-monde-20210805_27IBA OAWABGD5IQD7267L5WGWQ/> accessed 8 August 2021.

57 <https://www.lefigaro.fr/flash-actu/le-passe-sanitaire-et-la-vaccination-des-soignants-valides-par-le-conseil-constitutionnel-20210805>accessed 6 August 2021. 
the work-floor. In all likelihood, this drive will further pick-up speed and expand to other countries and categories of people as-well. This is would constitute a very illiberal move but not necessarily an illegal one because, as Anja Krasser ${ }^{*}{ }^{8}$ reminds us, 'compulsory vaccination may interfere with Article 2 ECHR, undeniably interferes with several aspects protected under Article 8 ECHR, and may conceivably interfere with Article 9 ECHR', provided no proper justification is given. Conversely, 'an interference is justified if it is based on an appropriate legal basis (prescribed by law), pursues a legitimate aim and is necessary in a democratic society'.

\section{The road ahead}

In view of all these topics, the ultimate question is not whether society will be transformed but whether the new normal of COVID-19-related restrictions constitutes a mere quantitative change or, rather, qualitative transformation of the tie between state and society.

The discussion above leads one to conclude that the ultimate lesson from the COVID-19 crisis will have had less to do with the temporary suspension of fundamental rights or with the assumption of powers by the executive than with the shaken trust between citizens and government. Indeed, virtually all Western governments have smoothly crossed a boundary that no-one a year ago would have thought it possible to step over: there has been an about-face from a literally and figuratively free society without borders ${ }^{*} 59$ to a permanent state of emergency in which fundamental rights have become conditional.

According to Allister Heath ${ }^{* 60}$, there is indeed a paradigm shift, a '1914 moment' as he calls it:

The travel bans and quarantine hotels are this new philosophy's first, most shocking manifestation. For the first time since the mid-Forties, governments are preventing citizens from leaving their countries via hard borders. In Britain, it is now against the rules to go on holiday, and guarded hotel quarantines are being imposed on citizens returning from high-risk countries. This policy will surely be extended drastically as more mutant virus strains pop up across the world [...]. In just nine months, border shutdowns have gone from inconceivable impositions in the modern, easyJet world to one of the state's key public health tools. Whether one believes this new approach to be vital to save lives, or a calamity, is irrelevant: it is the new normal. Travel bans and quarantine hotels won't be a one-off. There will be more outbreaks of infectious diseases in the near future, and also false alarms, and they will all be accompanied by crippling restrictions.

In all fairness, one has to admit that there are mitigating circumstances in at least some sense: the curtailing of hereditary freedoms occurred in response to a crisis of the utmost seriousness ${ }^{* 61}$, it continues to receive the acceptance and support of the majority of the population ${ }^{* 62}$, and - notwithstanding conspiracy theories - there is no proof that the restrictions were carried out by sinister design.

However, it is something altogether different whether the executive power is at the origin of a myriad of legal 'technicalities' or whether it sets itself up in the place of the constitutional legislator, places society in shackles, and thereby thoroughly undermines both the letter and the spirit of the law.

Lord Sumpton cut to the core of the problem when stating that 'governments who can simply turn social existence on and off at will [...] treat us as passive instruments of state policy." ${ }^{*} 63$

58 A Krasser, 'Compulsory Vaccination in a Fundamental Rights Perspective: Lessons from the ECtHR', ICL Journal (2021) 15:2, 207-233. - DOI: https://doi.org/10.1515/icl-2021-0010. See also n 22.

59 According to Peter Sloterdijk, unlimited mobility or kinetics, both in daily life and in politics, is the credo of modernity, per Eurotaoism. Zur Kritik der politischen Kinetik, (1989), Frankfurt/M.

60 See <www.telegraph.co.uk/news/2021/01/27/covid-1914-moment-post-cold-war-globalised-order/> accessed 13 July 2021.

61 Although in hindsight some nuance is evident with regard to the total death toll relative to the total number of infected persons, the vast majority of whom are asymptomatic. COVID-19 has displayed nowhere near the lethality of other epidemics such as the medieval Black Death or the Ebola virus in central Africa.

62 According to Foucault, power is not to be confounded with force, where the latter is the one-sided exercise of violence for the sake of control. Power resides in the acquiescence of the ruled, in that it justifies itself through truth claims; see Michel Foucault, 'Politics and Reason' in Lawrence Kritzman (ed), Michel Foucault: Politics, Philosophy, Culture (1988) 84.

63 See <www.telegraph.co.uk/opinion/2020/12/19/simple-truth-lockdowns-do-not-work/> accessed 13 July 2021. 
He does not suggest that a dark plan is being hatched by the current governments either, but he is right in fearing the implied danger of experiments by 'apprentice sorcerers" ${ }^{*} 64$ going awry. After all, this has happened before, as with the late Weimar Republic's tinkering with Article 48 of the German Constitution and its cavalier attitude toward presidential emergency decrees, an attitude that was soon to be recycled in 1933 by a very different breed of politician ${ }^{*} 65$.

Therefore, it is always prudent to be on guard against the subtle beginnings of any new authoritarianism, 'especially if its presents itself as benign because', as Janet Daley puts it, 'the case for overthrowing it seems so much less urgent and the pretext for maintaining it so apparently virtuous' .66

64 A famous theme in literature, spanning more than two thousand years, from The Liar by Lucian of Samosata (in the second century BC) via Goethe and Dukas to Walt Disney's Fantasia (1940).

65 Issued right after the Reichstag fire, the Verordnung des Reichspräsidenten zum Schutz von Volk und Staat of 28 February 1933 (RGBI I, S. 83) served as legal cover for the first wave of suppression by the Nazis.

66 <https://www.telegraph.co.uk/news/2021/07/24/scared-wits-covid-paranoia-britons-long-repent-submit-controlled/?li_ source=LI\&li_medium=liftigniter-rhr $>$. 